Sirman Ya. V., Preys N. I., Savytskyi I. V. Study of reduction of antioxidant protection in the pathogenesis of experimental diabetic retinopathy. Journal of Education, Health and Sport. 2020;10(11):306-311. eISSN 2391-8306. DOI http://dx.doi.org/10.12775/JEHS.2020.10.11.031

https://apcz.umk.pl/czasopisma/index.php/JEHS/article/view/JEHS.2020.10.11.031

https://zenodo.org/record/4549564

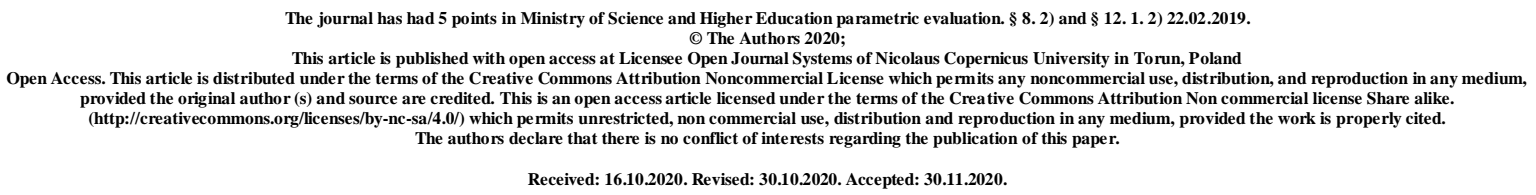

UDC: 616-06: 616-092.9

\title{
STUDY OF REDUCTION OF ANTIOXIDANT PROTECTION IN THE PATHOGENESIS OF EXPERIMENTAL DIABETIC RETINOPATHY
}

\author{
Ya. V. Sirman, N. I. Preys, I. V. Savytskyi \\ SE "Ukrainian Research Institute of Transport Medicine of the Ministry of Health of \\ Ukraine"
}

Sirman Yana Vadymivna, Candidate of Medical Sciences, Senior Researcher, Laboratory of Occupational Pathology, State Enterprise "Ukrainian Research Institute of Transport Medicine of the Ministry of Health of Ukraine"

Preys Natalia Ihorivna, Candidate of Medical Sciences, Senior Researcher, Laboratory of Occupational Pathology, SE "Ukrainian Scientific Research Institute of Transport Medicine Ministry of Health of Ukraine"

Savytskyi Ivan Volodymyrovych, Doctor of Medical Sciences, Professor, Head of the Department of Biomedical Sciences Odessa International Medical University

Author for correspondence: Savytskyi Ivan Volodymyrovych. 65039, Odessa, Fontanskaya road 4th, 29, tel. + 38050-381-21-83, e-mail farmakod@ukr.net

\section{Abstract}

The prevalence of diabetes mellitus (DM) is growing among the population of countries of the world, depending on the region, the level of economic development of the country, gender and age. The antioxidant system plays an important role in protecting the cells of the body from permanent and numerous damage that occurs due to the pathological influence of free radicals. Antioxidant enzymes, and peroxidases in particular, block the 
initiation of chain oxidation processes, preventing, among other things, the processes of DNA damage by free radicals that provoke the process of mutagenesis.

Our results indicate the development of oxidative stress in the pathogenesis of experimental diabetic retinopathy, as evidenced by a pronounced decrease in the activity of the antioxidant defense enzyme under the conditions of our study.

Already on the thirtieth day of the development of experimental diabetic retinopathy, a decrease in peroxidase activity was observed, followed by the progression of pathological changes on the sixtieth day of the study.

The most pronounced decrease in the activity of the studied marker of antioxidant defense was found at the 3rd stage of the experiment.

Key words: diabetic retinopathy; diabetes mellitus; experimental model; oxidative stress; peroxidase

Introduction. The prevalence of diabetes mellitus (DM) is growing among the population of the world depending on the region, the level of economic development of the country, gender and age. Thus, according to the International Diabetes Federation (IDF), there is a tendency for the greatest prevalence of diabetes among the urban working population of developing countries, among people aged 40-59, approximately equally male and female. It is projected that by 2030 the number of patients with diabetes will increase to 552 million $(9.9 \%$ or 1 patient with diabetes per 10 healthy adults), and by 2035 - to 592 million (10.1\%) [1]. Moreover, according to the IDF, there are up to 183 million people in the world with undiagnosed diabetes, which is $50 \%$ of diagnosed cases. If we summarize the number of patients with this pathology and impaired glucose tolerance, then almost every 10-12 inhabitants of the planet have pancreatic dysfunction [2-7].

The antioxidant system plays an important role in protecting the body's cells from permanent and numerous damage caused by free radicals. Antioxidant enzymes, and peroxidases in particular, block the initiation of chain oxidation processes, including the prevention of DNA damage by free radicals that provoke the process of mutagenesis.

Purpose of the study: analysis of changes in peroxidase activity in experimental diabetic retinopathy.

Materials and methods. The study was performed on white Wistar rats weighing 180-200 g. According to the tasks, the animals were divided into 2 groups:

$1^{\text {st }}$ group - 60 intact animals;

Group 2 - 60 animals, which simulated diabetic retinopathy without further correction. 
Type 2 diabetes mellitus and diabetic retinopathy were modeled by intraperitoneal administration of streptozotocin (Sigma, USA) dissolved in $0.1 \mathrm{M}$ citrate buffer with a $\mathrm{pH}$ of 4.5 [8]. The dose of streptozotocin $55 \mathrm{mg} / \mathrm{kg}$ body weight was divided into two injections. The introduction of streptozotocin was preceded by a high-fat diet for 28 days [9].

Animals were removed from the experiment by decapitation under light ether anesthesia in accordance with the "Rules for performing work using experimental animals", approved by the Order of the Ministry of Health of Ukraine № 249 from 01.03.2012 and the Law of Ukraine № 3447-IV "On protection of animals from cruelty" (as amended from 15.12.2009 and from 16.10.2012).

Blood was taken from the retroorbital venous plexus, which lies in orbit behind the eyeball. The puncture was performed in a circular motion with a glass pipette with an extended capillary, the tip of which is ground at an angle of $45^{\circ}$. The conjunctival sac was punctured in the medial corner of the eye between the eyeball and the orbit. After puncture, the pipette was inserted to a depth of $2-4 \mathrm{~mm}$ behind the eyeball. Control of entering the venous plexus - filling the pipette capillary with blood (Dyakonov AV, Khrikina IS, Hegai AA, etc., 2013).

\section{Statistical processing of the obtained results}

To detect changes in the studied indicators between different groups and at different stages, we used parametric statistical methods, which are based on the operation of the parameters of the statistical distribution (mean and variance).

The methods used are designed for normally distributed data, so we checked all data for normality using the criterion of asymmetry and excess EI Pustylnyk. According to this criterion, the distribution does not differ from normal if the calculated empirical values of asymmetry and excess do not exceed the critical, ie $A_{e m p}<A_{C r}, E_{e m p}<E_{c r}$, where $A_{e m p}$ and $E_{e m p}$ - calculated values of asymmetry and excess, and

$$
A_{c r}=3 \cdot \sqrt{\frac{6 \cdot(n-1)}{(n+1) \cdot(n+3)}}, E_{c r}=5 \cdot \sqrt{\frac{24 \cdot n \cdot(n-2) \cdot(n-3)}{(n+2)^{2} \cdot(n+3) \cdot(n+5)}},
$$

respectively, their critical values [10].

All the data we consider were normally distributed, so you can compare the average values of the samples in pairs. Note that in subsequent comparisons, we perform comparisons in independent samples. These will be comparisons between different groups of animals or 
comparisons between the same group of animals (but since there is no correspondence between animals in the samples, they will also be independent).

Before comparing the averages of the two samples, it should be ascertained whether the variances are homogeneous. For this purpose it is necessary to carry out a check for homosketicity (homogeneity of dispersions).

Statistical hypotheses will be as follows:

$\mathbf{H}_{0}$ : the variance in group 1 does not differ from the variance in group 2.

$\mathbf{H}_{1}$ : the variance in group 1 is greater than the variance in group 2. The

hypotheses in the criterion are directed, so the criterion is one-sided. Hypothesis $\mathrm{H}_{0}$ is rejected when $F_{e m p}>F_{c r}$. This is evidenced by the $p$-value - the probability of error to reject the null hypothesis when it is correct. In various experiments, take $\mathrm{H}_{0}$ when $p$-value (set significance level), and reject $\mathrm{H}_{0}$ when $p$-value $<$. In all subsequent calculations, we chose a standard level of significance $=0.05$.

The comparison of the averages is performed using ${ }^{t}$ Student's-test. When comparing the average directional hypotheses will be as follows:

$\mathbf{H}_{\mathbf{0}}$ : the average of group 1 does not differ from the average of group 2.

$\mathbf{H}_{1}$ : the average of group 1 is greater than the average of group 2.

To decide the absolute value of the calculated $t$ is compared with one-sided critical. If $\left|t_{e m p}\right|<t_{c r}$, the null hypothesis can not be rejected. Here it is similarly possible to draw a conclusion and on $p-$ value.

All tests will be performed in the statistical package PASW Statistics 18. We will use the t-test procedure for independent samples, which immediately compares variances and means.

In subsequent tests, we will note whether the average values differ. If they are different, you need to specify this difference. The results of the t-test give an answer about the equality or difference of the mean values, but they do not allow to accurately measure the difference between the mean values. Note that this difference is quite conditional. Thus, we demonstrated a comparison of the mean values between different groups of animals.

\section{Results of the study and their discussion:}

Peroxidase activity in intact animals was constant throughout the experiment, indicating the initial homogeneity of the study groups. 
In the second group, which did not correct the pathological process, revealed a decrease in this marker by $49.28 \%$ ( $\mathrm{p}<0.001$ ) relative to normal in the first stage. In the second stage, the activity of the indicator is lower by $64.78 \%$ ( $p<0.001$ ) compared to the data of intact animals and by $10.39 \%(\mathrm{p}<0.01)$ relative to the results of the 1 st stage. In the third stage, the activity of this marker is $75.03 \%(\mathrm{p}<0.001)$ lower relative to the intact group. Compared with the first stage, there is a decrease of $17.25 \%(\mathrm{p}<0.001)$.

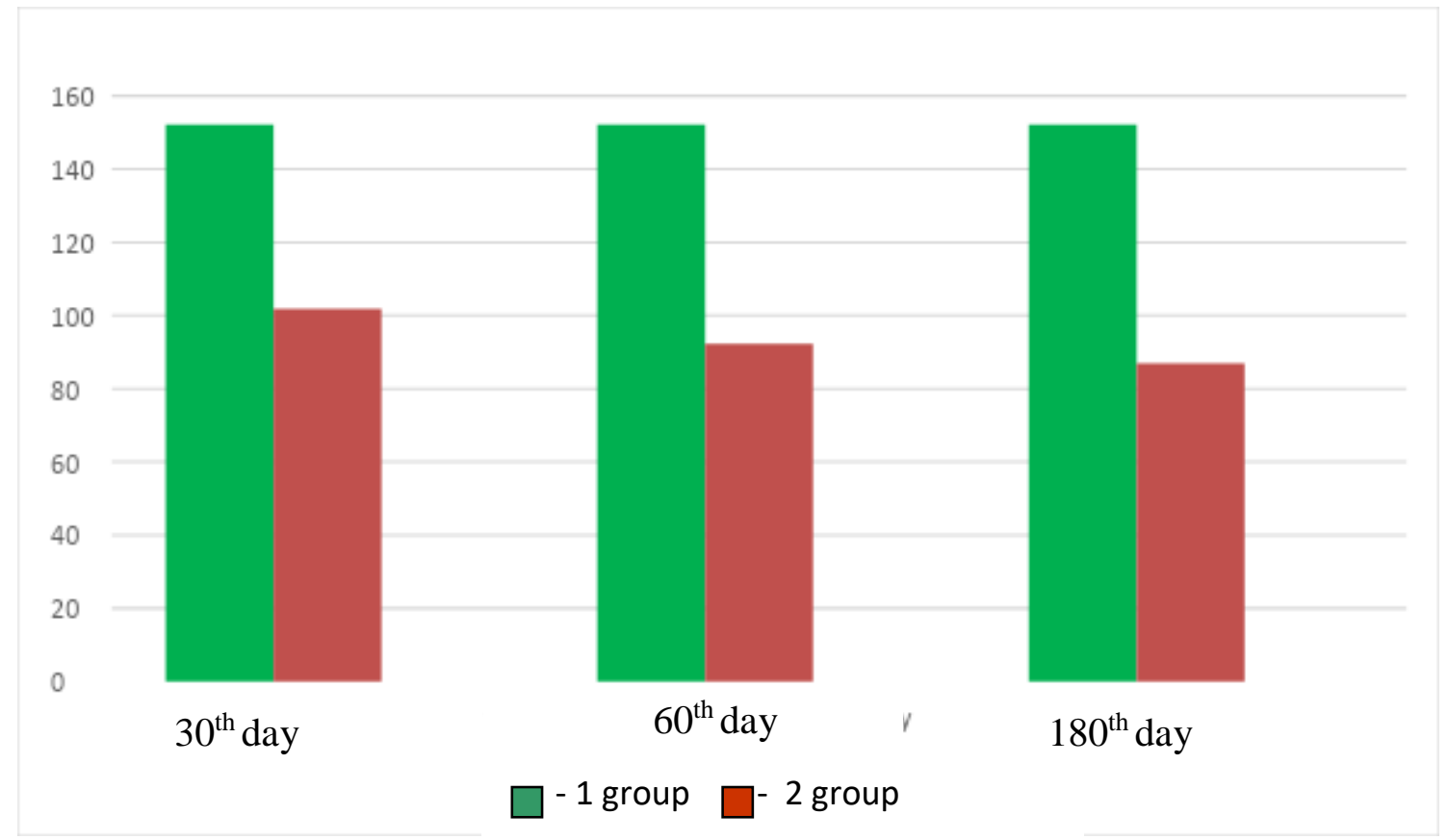

Figure 1. - The level of peroxidase in the blood of experimental animals with simulated diabetic retinopathy and with different methods of its correction on the $30^{\text {th }}, 60^{\text {th }}$ and $180^{\text {th }}$ day $(\mathrm{M} \pm \mathrm{m})$

\section{Conclusions:}

1. Our results indicate the development of oxidative stress in the pathogenesis experimental diabetic retinopathy, as evidenced by a marked decrease in the activity of the enzyme antioxidant protection in our study.

2. Already on the $30^{\text {th }}$ day of development of experimental diabetic retinopathy there is a decrease in peroxidase activity with subsequent progression of pathological changes on the 60th day of the study ( $p<0,001)$.

3. The most pronounced decrease in the activity of the studied marker of antioxidant protection was detected in the 3rd stage of the experiment $(\mathrm{p}<0.001)$. 


\section{References}

1. Tsitovsky MN Statistical, clinical and morphological aspects of the impact of diabetes on the state of the cardiovascular system. Scientific Bulletin of Uzhhorod University, series "Medicine". 2017. № 1 (55). Pp. 168-177.

2. Diabetic microangiopathy: Pathogenetic insights and novel therapeutic approaches / R. Madonna et al. Vascul Pharmacol. 2017. № 90. R. 1-7.

3. Sorokina YuA, Lovtsova LV. Koeffitsienty okislitelnoho stressa kak sposob personifitsirovaniya farmakoterapii $\mathrm{v}$ debyute SD 2 tipa. Meditsina $i$ farmakolohiya : elektron. nauchn. zhurn. [Internet] 2014; 1 (14). Available from: https://7universum.com/ru/med/archive/item/1868 (Russian).

4. Pasechnikova NV, Moroz OA. Issledovanie vliyaniya kvertsetina i lipoata na protsessy perekisnoho okisleniya lipidov $v$ setchatke pri eksperimentalnom diabete. Oftalmolohicheskiy zhurnal. 2016; 4 (470):38-42 (Russian).

5. Pasechnikova NV, Naumenko VA, Zborovskaya AV. Sostoyanie hematoretinalnoho barera pri diabeticheskoy retinopatii po dannym flyuorometri. Oftalmolohichniy zhurnal. 2008; 5:4-7 (Russian).

6. Barber AJ. A new view of diabetic retinopathy: a neurodegenerative disease of the eye. Prog. In Neuro-Psychopharm. \& Biol. Psych. 2003; 27:283-290.

7. Leus NF. Metabolicheskie mekhanizmy razvitiya i perspektivy medikamentoznoho lecheniya diabeticheskoy retinopatii. Oftalmolohichniy zhurnal. 2003; 5:75-80 (Russian).

8.Preclinical studies of drugs: a method. rivers / for ed. Corresponding Member NAMS of Ukraine, acad. OV Stefanova. K.: Avicenna, 2001. 528 c.

9.Biomarkers of diabetic retinopathy / MV Budzinskaya, DV Lipatov, VG Pavlov, DV Petrachkov // Diabetes mellitus. 2020. № 1 (23). Pp. 88-94.

10. Lupan IV, Avramenko OV, Akbash KS Computer statistical packages: a textbook. - 2nd type. - Kirovograd: "CODE" 2015. - 236 p. 